\title{
What is the Role of Laminin Receptor 1 in Human Reproduction?
}

\author{
Mertihan Kurdoglu ${ }^{*}$, Zehra Kurdoglu ${ }^{2}$
}

\section{Dear Editor,}

The accumulated data related to the recently discovered functions of laminin receptor 1 (LR1) in the early stages of placentation (1-5) made us to think that it may also have an important role in human reproduction, which may be regarded as a very new job for this multifunctional protein overexpressed in many types of cancer and is very well known for its important roles in tumour-cell migration and invasion.

In human reproductive physiology, one of the essential steps for the development of a normal pregnancy is the invasion of uterine decidua and myometrium by fetally derived extravillous trophoblast cells and the associated spiral artery transformation which proceed in a complex but stereotyped manner (6). Within this process, laminins which are a family of well-described extracellular matrix glycoproteins have many effects on cell adhesion, differentiation, migration, signalling and invasion. One of the molecules that may also play a key role in both normal and pathologic trophoblast invasion is a non-integrin-type receptor of laminins, laminin receptor 1 (LR1) which acts as a cell-surface receptor of laminin in the interactions for these biological processes. Together with Nagymanyoki et al. (4) we have previously shown LR1 in the decidua of normal and molar human pregnancies (1).

Based on the pathological data, there is a growing body of evidence that impaired early trophoblastic invasion and more consistently, restricted endovascular invasion may be associated with preeclampsia which is an almost exclusively human pregnancy-specific syndrome characterized by new-onset proteinuria and hypertension occurring usually after 20 weeks of gestation. For the first time in the literature, we showed that decreased LR1 expression may be related to the shallow trophoblastic invasion in human placentas from preeclamptic patients (2). In the following studies, it has been suggested that knockdown of LR1 may inhibit trophoblast cell invasion and migration by modulating matrix metalloproteinase/tissue inhibitor of metalloproteinase (MMP/TIMP) expression via the ERK (ex- tracellular signal-regulated kinases) pathway (5).

A recent study has demonstrated that Brucella replicates in several human trophoblast subpopulations and can interfere with the invasive capacity of extravillous trophoblast-like cells in vitro (7). In one of the largest series of pregnancies complicated with brucellosis, we have also showed that brucellosis in pregnancy is associated with increased incidence of spontaneous abortions not only in livestock but also in human pregnancies (8). At this point, we hypothesised that LR1 may also have a role in diminished invasive capacity of extravillous trophoblast-like cells in abortions related to Brucella infections (3). Although it has been suggested that failed trophoblast invasion and spiral artery transformation do not have a pivotal role in the pathogenesis of early miscarriage (6), the abortions related to Brucella infections may be exceptional.

As a conclusion, limited present data related to the role of laminin receptor-1 in human reproduction supports the idea that it may have an important role in the development of the fundamentals of a normal pregnancy. There is enough evidence to show that shallow trophoblastic invasion in preeclampsia may be associated with the decreased LR1 expression in the cytotrophoblasts and syncytiotrophoblasts in the placentas of these patients. However, the role of LR1 in some other major obstetrical syndromes implicated with defective deep placentation such as preeclampsia with fetal growth restriction, intrauterine growth restriction, preterm premature rupture of the fetal membranes, preterm birth as well as abortions linked to Brucella infection needs to be elucidated with further studies.

\section{References}

1. Kurdoglu M, Bayram I, Kolusari A, Erten R, Adali E, Bulut G, et al. Expression of laminin receptor 1 in gestational trophoblastic diseases and normal placenta and its relationship with the development of postmolar tumors. Gynecol Oncol 2009; 114: 306-9. doi: 10.1016/j.ygyno.2009.05.010 
2. Kurdoglu M, Kurdoglu Z, Ozen S, Kucukaydin Z, Bulut G, Erten R, et al. Expression of laminin receptor 1 in human placentas from normal and preeclamptic pregnancies and its relationship with the severity of preeclampsia. J Perinat Med 2011; 39: 411-6. doi: 10.1515/JPM.2011.024

3. Kurdoglu M, Sendag S, Kurdoglu Z. Is there a role of laminin receptor-1 in Brucella related abortions? Reproduction in Domestic Animals 2015; 50: 48. doi: 10.1111/rda. 12498

4. Nagymanyoki Z, Callahan MJ, Parast MM, Berkowitz RS, Mok SC, Fulop V. Overexpression of laminin receptor 1 on decidual cells in partial and complete mole. Gynecol Oncol 2008; 108: 121-5. doi: 10.1016/j. ygyno.2007.08.097

5. Wang L, Zhang D, Yu Y, Guan H, Qiao C, Shang T. RNA interference-mediated silencing of laminin receptor 1 (LR1) suppresses migration and invasion and down-regulates matrix metalloproteinase (MMP)-2 and MMP-9 in trophoblast cells: implication in the pathogenesis of preeclampsia. J Mol Histol 2013; 44: 661-8. doi: 10.1007/s10735-013-9515-6

6. Ball E, Robson SC, Ayis S, Lyall F, Bulmer JN. Early embryonic demise: no evidence of abnormal spiral artery transformation or trophoblast invasion. J Pathol 2006; 208: 528-34. doi: 10.1002/path.1926

7. Salcedo SP, Chevrier N, Lacerda TL, Ben Amara A, Gerart S, Gorvel VA, et al. Pathogenic brucellae replicate in human trophoblasts. J Infect Dis 2013; 207: 1075-83. doi: 10.1093/infdis/jit007

8. Kurdoglu M, Adali E, Kurdoglu Z, Karahocagil MK, Kolusari A, Yildizhan R, et al. Brucellosis in pregnancy: a 6-year clinical analysis. Arch Gynecol Obstet 2010; 281: 201-6. doi: 10.1007/s00404-0091106-0

Copyright $\odot 2015$ The Author(s); This is an open-access article distributed under the terms of the Creative Commons Attribution License (http://creativecommons.org/licenses/by/4.0), which permits unrestricted use, distribution, and reproduction in any medium, provided the original work is properly cited. 